\title{
OVERVIEW OF SANITATION HYGIENE AND BACTERIOLOGICAL QUALITY OF FOOD AND EQUIPMENT ON FOOD MANAGEMENT SITES AT JUANDA AIRPORT, SURABAYA IN 2019
}

\author{
Devi Shintiya Chilmi ${ }^{1}$, Ririh Yudhastuti ${ }^{1}$, Bangun Cahyo Utomo ${ }^{2}$ \\ ${ }^{1}$ Department of Environmental Health, Faculty of Public Health, Airlangga University, Surabaya, Indonesia \\ ${ }^{2}$ Environmental Risk Control Sector, Surabaya Class I Port Health Office, Indonesia \\ Correspondence address: Devi Shintiya Chilmi \\ Email: devischilmi@gmail.com
}

\begin{abstract}
Sites for managing and providing food for the community contribute to the emergence of major foodborne diseases. The airport gives notes on how important it is to prevent food-borne diseases. This study aimed to review the sanitary hygiene and bacteriological quality of the food and equipment on food management sites in Terminal 1 of Juanda Airport, Surabaya. This was a descriptive study using a cross-sectional study design. The research population was all 53 food management sites in Terminal 1 of Juanda Airport. A large sample of four food management sites were taken based on the number of food management sites offered to be surveyed every month. The research variables were sanitation hygiene and bacteriological quality of the food and equipment on the food management sites. Data collection on sanitation hygiene was done through observation and interview. Data collection on bacteriological quality of food and equipment was performed by taking and checking food samples and equipment from each food management site. The assessment of sanitation hygiene on the four food management sites in Terminal 1 of Juanda Airport received a score of $>700$. The results of bacteriological food quality showed that Escherichia coli was found in food samples produced by one food management site. The results of bacteriological equipment quality showed that there was no Escherichia coli on the equipment used by four food management sites, but the total plate count value on the equipment was $>0$. All food management sites in Terminal 1 of Juanda Airport met sanitation hygiene requirements but did not meet the bacteriological quality requirements for equipment because the total plate count value exceeded the threshold value. In terms of bacteriological food quality, most of the food management sites met the health requirements.
\end{abstract}

Keywords: sanitation and hygiene, Escherichia coli, total plate count, airports

\section{INTRODUCTION}

Humans occupy the top rank in the food chain; it means that food is a basic human need to maintain survival and a source of energy to carry out daily activities. Not only does it need to have optimal nutritional values, but also the food consumed by humans must also be managed in a hygienic manner. Proper food management i.e., the storage method and transportation method that meet the requirements can guarantee safety of the food for consumption. Safe and healthy food for consumption does not contain microorganisms or other substances that are potentially harmful to human health. In addition, the hygiene and sanitation of food management areas also have an effect on bacterial contamination such as Escherichia coli and Salmonella sp. on food (cYunus et al, 2015).

Until now, cases of food poisoning in Indonesia are still high. The 2017 POM Agency Annual Report Data showed the number of cases of drug and food poisoning nationally throughout Indonesia was 4,643 cases in 2017. The main cause of these poisoning cases was the food group, with as many as 1,226 cases (336 cases of food, 890 cases of drinks) (BPOM RI, 2018). Besides, the 2017 Indonesian Health Profile mentioned diarrhea outbreaks affected residents in 12 provinces in Indonesia. The number of diarrhea sufferers was 1,725 , and there were 34 deaths caused by diarrhea (Indonesian Ministry of Health, 2018). Food poisoning can occur as a result of several factors, including poor personal hygiene, unclean food processing equipment, and improper and unhealthy 
food handling methods (Amikawati et al, 2017).

Food safety is something that needs attention. Unsafe food can create a cycle of disease. Given the possibility of diseases that can be transmitted through food and drink, monitoring the hygiene and sanitation of food management places is an important effort in all public health activities. Food hygiene and sanitation are needed to protect food from contamination and disease-transmitting microorganisms in order to prevent food borne diseases from occurring. Food contaminated by microorganisms or toxins entering the human digestive tract can cause diseases such as diarrhea, typhoid, gastrointestinal syndrome, and worm infections (Herman et al, 2015). Food hygiene and sanitation in food processing facilities at airports are expected to reduce, minimize, and eliminate negative impacts that may arise from the ongoing food processing.

The Port Health Office is one of the technical implementation units within the Indonesian Ministry of Health which consists of several divisions, one of which is Environmental Risk Control. This division has the task of carrying out supervision of sanitation hygiene in food management sites and securing food and beverages in the airport and port environment. Supervision for food and beverage security starting from the selection of raw materials to the serving of food are required to protect food and beverages. This must be done to reduce the possibility of contamination and ensure that the food is safe for consumption and does not cause harm, poisoning, or disease in humans (Indonesian Ministry of Health, 2007).

Airports have a very important role in preventing the spread of various diseases that may occur. Airports provide basic and supporting facilities, one of which is restaurant. Restaurants which provide food for the public have the potential to cause health problems or spread diseases caused by the food they produce; therefore, the hygiene and sanitation of food management sites at airports require further supervision to prevent food borne diseases. Juanda Airport in Surabaya is one of the working areas of the Class I Surabaya Port Health Office which has the authority to supervise the sanitation hygiene of the food management sites there. Speaking about the issue, this study aimed to describe the sanitation hygiene and bacteriological quality of food and equipment on the food management sites at Juanda Airport, Surabaya.

\section{METHODS}

This was a descriptive observational study that used a cross sectional study design. All 53 food management sites in Terminal 1 of Juanda Airport became the research population. The sample size in this study was 4 food management sites determined based on the number of sites accepting survey schedule on a monthly basis. The food management sites which were surveyed in February 2019 were food management sites A, B, C, and D.

The research variables were sanitation hygiene and bacteriological quality of processed food, as well as the bacteriological quality of equipment used by the food management sites. The data collection on hygiene was done by observing the selected food management sites. An interview was also carried out with a food labor at each food management site to investigate the personal hygiene of the food labor. The observation and interview guide was the assessment sheet of sanitation hygiene which is based on the Indonesian Ministry of Health Regulation Number 1098 of 2003 concerning Restaurant Hygiene and Sanitation. A food management site is declared having good sanitation hygiene if the total score obtained in the assessment reaches a minimum of 700 (Indonesian Ministry of Health, 2003).

The bacteriological quality of food and equipment was assessed by examining food samples and equipment from each 
food management site. The food samples underwent a bacteriological examination with the Escherichia coli parameters. The sampled food was food served warm with around $50-70^{\circ} \mathrm{C}$. The swab method was used for sampling the equipment, which was then checked with the parameters of the total plate number (ALT) and Escherichia coli. Examination of food samples was carried out at the Surabaya Health Laboratory Center.

The variables of hygiene, sanitation, food quality, and equipment quality were analyzed by comparing the scores obtained and the results of the bacteriological food and equipment quality as regulated in the Regulation of the Indonesian Ministry of Health Number 1098 of 2003 concerning Restaurant Hygiene and Sanitation. A food management site was declared having sanitary hygiene if it obtained a minimum score of 700 . Food quality was declared to meet health requirements if no Escherichia coli was found in the food (level $=0$ per gram of food sample). Meanwhile, the quality of the equipment was declared to meet the health requirements if the germ count or ALT was 0 .

This study has passed the ethical clearance by the Health Research Ethical Clereance Committee, Faculty of Dental Medicine, Universitas Airlangga with the
Certificate No. $344 \quad$ / HRECC.FODM/VI/2019.

\section{RESULTS}

\section{Food Hygiene and Sanitation Assessments on Food Management Sites at Terminal 1 of Juanda Airport, Surabaya}

Table 1 shows the results of food hygiene and sanitation assessments on the four food management sites, all of which received a score of more than 700 . The highest score was obtained by food management site $\mathrm{B}$, while the lowest score was obtained by food management site D. Food management site A had a score of 796.5; food management sites B had a score of 813.5; food management sites $C$ had a score of 798.5, and food management sites D had a score of 752.5 .

\section{Bacteriological Inspection of Food on Food Management Sites at Terminal 1 of Juanda Airport, Surabaya}

Table 2 shows that the examination of food samples obtained negative results, meaning there was no Escherichia coli in the food samples taken from food management sites A, B, and C. Meanwhile, the food samples taken from food management site D had Escherichia coli.

Table 1. Results of Food Hygiene and Sanitation Assessments on Food Management Sites at Terminal 1 of Juanda Airport, Surabaya

\begin{tabular}{lccccc}
\hline \multirow{2}{*}{ Variables } & Maximum & \multicolumn{4}{c}{ Food Management Sites } \\
\cline { 3 - 6 } & Score & A & B & C & D \\
\hline Location and building & 100 & 84.5 & 83.5 & 84.5 & 81.5 \\
\hline Sanitary facilities & 150 & 115 & 117 & 123 & 97 \\
\hline $\begin{array}{l}\text { Kitchen, dining room and } \\
\text { grocery store }\end{array}$ & 150 & 117 & 127 & 111 & 104 \\
\hline $\begin{array}{l}\text { Food ingredients and } \\
\text { finished food }\end{array}$ & 110 & 77 & 77 & 77 & 77 \\
\hline Food processing & 50 & 50 & 50 & 50 & 50 \\
\hline Storage of food stuff & 90 & 78 & 86 & 78 & 78 \\
\hline Food serving & 50 & 40 & 40 & 40 & 40 \\
\hline Equipment & 150 & 120 & 120 & 120 & 120 \\
\hline Labor & 150 & 115 & 113 & 115 & 105 \\
\hline Total Score & $\mathbf{1 , 0 0 0}$ & $\mathbf{7 9 6 . 5}$ & $\mathbf{8 1 3 . 5}$ & $\mathbf{7 9 8 . 5}$ & $\mathbf{7 5 2 . 5}$ \\
\hline
\end{tabular}


Table 2. Bacteriological Quality Inspection Results of Food on Food Management Sites at Terminal 1 of Juanda Airport, Surabaya

\begin{tabular}{lcc}
\hline Food Management Sites & Type of Food & $\begin{array}{c}\text { Bacteriological Examination } \\
\text { Status } \\
\text { (Escherichia coli) }\end{array}$ \\
\hline A & $\begin{array}{c}\text { Coconut-milk } \\
\text { vegentable soup }\end{array}$ & Negative \\
\hline B & Corn soup & Negative \\
\hline C & Tamarind vegetable & Negative \\
\hline D & soup & Positive \\
\hline
\end{tabular}

Table 3. Bacteriological Quality Inspection Results of Equipment on Food Management Sites at Terminal 1 of Juanda Airport, Surabaya

\begin{tabular}{lccc}
\hline & $\begin{array}{c}\text { Food } \\
\text { Management } \\
\text { Sites }\end{array}$ & Types of Equipment & \multicolumn{2}{c}{ Bacteriological Examination Status } \\
\cline { 3 - 5 } & Escherichia coli & ALT \\
\hline $\mathrm{A}$ & Plate & Negative & 10 \\
\hline $\mathrm{B}$ & Soup bowl & Negative & 180 \\
\hline $\mathrm{C}$ & Tablespoon & Negative & 160 \\
\hline $\mathrm{D}$ & Bowl & Negative & 530 \\
\hline
\end{tabular}

Bacteriological Quality Inspection of Equipment on Food Management Sites at Terminal 1 of Juanda Airport, Surabaya

Table 3 presents that the food management sites A, B, C, and D were not contaminated by Escherichia coli bacteria. However, the ALT of the equipment used by each food management site was more than 0 which exceeded the threshold value. The number of ALT in food management site A was 10 colonies, food management site B 180 colonies, food management site C 160 colonies, and food management site D 530 colonies.

\section{DISCUSSION}

Overview of Hygiene and Sanitation on Food Management Sites at Terminal 1 of Juanda Airport, Surabaya

The results indicated that 4 food management sites at Terminal 1 of Juanda Airport in February 2019 obtained a total score of more than 700. All the food management sites had met the sanitation requirements and were declared to have proper sanitary hygiene. This followed the Regulation of the Indonesian Ministry of Health Number 1098 of 2003 concerning Restaurant Hygiene and Sanitation.

Table 1 explains food processing on each food management site that had met the maximum score. However, some others still received a score far from the maximum score. The result of this study is in line with research conducted by Dakwani (2019) showing the food processing conditions on food management sites in Gudang 100 met the requirements because food labor used food tongs, spoons, forks, and plastic gloves to protect food from cross-contamination.

Location and building variables on each four food management sites did not meet the requirements in the Regulation of the Indonesian Ministry of Health Regulation Number 1098 of 2003 concerning Restaurant Hygiene and Sanitation. The food management buildings had broken doors. Some areas did not even have doors, and thus there was a high possibility of insects and rats entering the 
buildings. The presence of insects and mice on a food management sitescan be a source of disease transmission (Pulungan et al. 2013). This is similar to research by Dakwani (2019) who found that location and food management buildings in 100 warehouses at several depots did not yet meet the requirements according to the Regulation of the Indonesian Ministry of Health Number 1098 of 2003 concerning Restaurant Hygiene and Sanitation. Food management rooms were directly exposed to outside conditions, meaning that there was a great potential for pollution e.g.,incoming smoke, dust, rats, and insects to to enter the areas. The food management sites were located at Terminal 1 of Juanda Airport. However, the food management sites were not properly closed off, thereby leading to the risk of being contaminated by rats, insects, and other Disease-carrying animals.

Several variables that met the requirements included location, floor, walls, ventilation, lighting, roof, and ceiling. The four food management sites were located farther than 100 meters away from sources of pollution; therefore, no unpleasant or foul odor could enter from these sources. The buildings hosting the four food management had clean, flat, waterproof, and non-slippery floor even though the edges of the floors were not conical. The walls and ceiling looked clean and dry. The ventilation used was artificial ventilation with the help of a functioning air conditioner (AC). In other words, the room temperature was not hot and the air circulation was good. There was enough natural and artificial light to illuminate the room. Insufficient lighting can cause discomfort and eye fatigue, and reduce a person's productivity (Amikawati c 2017).

One of the sanitation facilities on the food management sites was clean water. The availability of clean water was sufficient as needed. The quality of clean water available on each site met the standard according to the Regulation of the Indonesian Ministry of Health Number 492 of 2010 concerning the Requirements for the Quality of Drinking Water which should be colorless, odorless, and tasteless.

Wastewater produced by each food management sites flew to closed, watertight, and smooth channels. The wastewater disposal channel on the sites met the requirements because the sewerage drainage flew smoothly, was closed and watertight, and was equipped with a grease trap to avoid freezing or clotting of oil which can cause blockages in the drain pipe and minimize adverse impacts on the environment. Wastewater needs to be processed before it is disposed of into water bodies. It ensures it does not pollute the environment and pose a danger to human health (Yogisutanti et al.2018).

Grease traps are also used at Kualanamu Airport to separate trash and dirt from water. Garbage and dirt originating from restaurants, offices, and toilets are channeled into the grease traps to prevent them from clogging the sewerage (Sudjanto et al. 2016).

However, the results of this study are different from research conducted by Pulungan et al. (2013), who noted that the disposal of wastewater on the food management sites at Terminal of Roro Port did not meet health requirements because the sewerage was clogged and discharge of wastewater was not smooth or the wastewater was stagnant around the sites. Things like this can lead to the proliferation of disease vectors.

Garbage officers got rid off the trash cans on the food management sites every 24 hours to avoid piles of garbage. However, there were two food management sites that still had open trash cans. The piles of garbage could become a nest for vectors and mice. Improper waste management will have a negative effect on human health because waste may become a breeding ground for vectors and rats. Besides, the use of open trash cans allows cockroaches, flies, mice, and other animals to infest the trash. This presents potential food contamination due to cockroaches, flies, rats, or other 
animals perching or touching the food and carrying bacteria that can cause health problems (Nuraini and Hajimi, 2014).

The most important place in food processing is kitchen. The kitchen should be taken under high consideration because it has a fairly high probability of contamination or spread of disease through vectors and food (Mutiarani, 2017). The results of this study indicated that the condition of the kitchen, dining room, and food warehouse on all food management sites did not meet the requirements. Overall, there were no written hygiene precautions for food labors or employees in the kitchen and no sinks for handwashing facilities in the dining room. Meanwhile, the grocery store didn't take proper precautions to keep insects and rats at bay.

The results of this study are similar to research conducted in restaurants in Losari Beach, Makassar City, which revealed that the kitchen, dining room, and grocery store did not meet health requirements. Some restaurants did not post hygiene precautions for food labors in the kitchen and had no automatic opening-andclosing doors in the dining room as well as insufficient food storage capacity (Fadly et al. 2017).

Food ingredients and processed food almost met the requirements since they were physically in good condition and registered in the lists of approved foods by the Indonesian Ministry of Health. Besides, there were no expired food ingredients or processed foods. The results of this study are in line with research conducted by Dakwani (2019) who said food ingredients on food management sites of Gudang 100 were not stored for a long time. The food handler stated they bought and prepared food ingredients from the market in the morning, and then the food ingredients were processed on the same day.

The food processing variable was the only variable fulfilled with the maximum score. Employees as food processors or food handlers wore complete clean uniform as required, such masks, headgear, and aprons. Clean work clothes ensure sanitation and hygiene in food management because such clothes are free from dust or dirt, which can indirectly cause food pollution. Morever, food handlers also used special tools to handle food. Food labors understand that long, dirty nails can contaminate the food.

A study stated that during food processing at the nutrition installation, Dr. Harjono paid less attention to sanitary work. The cooks seemed to taste the food by hand, and not all cooks wore aprons when processing food. There were food handlers who used aprons as hand rags after washing their hands. However, aprons should not be used to wipe hands and must be clean because dirty aprons can facilitate bacteria to breed (Jiastuti, 2018).

Workers on the four food management sites had not met the requirements because not all food handlers had attended courses and never done disease check-up. This is strongly inconsistent with the Regulation of the Indonesian Ministry of Health Number 1098 of 2003 concerning Restaurant Hygiene and Sanitation, which requires employees/food handlers to do check-up every six months and attend courses on food sanitation hygiene (Indonesian Ministry of Health, 2003). Employees and food handlers on all food management sitess did not have open wounds and did not suffer from infectious diseases or skin diseases such as scabies, sores, or boils. Food handlers maintained cleanliness by always washing their hands with soap and running water before and after processing food. In addition to these requirements, employees and food handlers did not smoke while working, had short and clean hair and nails, and wore clean and tidy clothes. Food handlers in particular always wore an apron and a cap. They have a big role in maintaining the quality of the food served because they may be agents that can cause food contamination. Contamination of food caused by employees or food handlers may happen through various means such as 
coughing, sneezing, and wounds on the hands (Amikawati et al. 2017).

\section{Descriptions of Bacteriological Food Quality on Food Management Sites at Terminal 1 of Juanda Airport, Surabaya}

The results showed that the bacteriological food quality at most food management sites met the health requirements as specified in the Regulation of the Indonesian Ministry of Health Number 1098 of 2003 concerning Restaurant Hygiene and Sanitation. It ensures that there are no Escherichia coli bacteria in the food. However, as seen from Table 2, some food still contained Escherichia coli bacteria.

Based on the regulaiton, prepared food served in restaurants must be in a good condition, i.e., not rotten or damaged. The food served should not contain Escherichia coli bacteria or have 0 bacteria per gram of food samples (Indonesian Ministry of Health, 2003).

The most common bacteria found in food is Escherichia coli. It is a major cause of food borne diseases in many countries. Some Escherichia coli bacteria can cause a disease or are pathogenic because they secrete Shiga-like toxins. Shiga toxinproducing Escherichia coli (STEC), enterohemo hemorrhagic Escherichia coli (EHEC), and verocytotoxic Escherichia coli (VTEC) are bacteria's names and can produce Shiga-like toxins. Escherichia coli O157: H7 is a type of STEC that is most often found in food or beverages. When a person is infected by STEC, he/she will feel abdominal pain accompanied by diarrhea for 24 hours or longer. If this disease is not treated quickly, complications will occur and endanger a person's life. The complications included necrosis of intestinal tissue, bloody diarrhea, and other acute and chronic diseases such as hemorrhagic colitis (HC) and hemolytic uremic syndrome (HUS). However, other researchers asserted that Escherichia coli is an early indication of pathogenic Escherichia coli strains such as Yersinia sp.,
Salmonella sp., or Shigella sp. that may cause food borne diseases or diarrhea; therefore, Escherichia coli cannot be considered as the main cause of diarrhea (Elfidasari et al., 2011; Rananda et al., 2016; Saridewi et al., 2016).

The main requirement in determining good food quality is reviewing sanitation because, directly or indirectly, environmental conditions are related to food processing and serving. Poor environmental sanitation, especially in the kitchen, can cause the area to become a source of food contamination. Escherichia coli is a bacterium that often contaminates food. Its presence in water or food has a significant relationship with the discovery of pathogenic germs in food. Escherichia coli is used as an indicator of water or food contamination for microbiological requirements because it may indicate human fecal contamination. Contaminated food or drinks can indicate that sanitation practices are not being implemented properly (Kurniadi et al. 2013).

In addition to food processing, open serving of food can also result in contamination by bacteria, dust, and flies. Personal hygiene in food handlers e.g., handwashing before and after touching food, therefore, has an influence on food quality and the occurrence of contamination in food. Despite food processing and environmental conditions, personal hygiene in food handlers also needs to be considered to prevent food contamination. Maulana's (2018) research noted similar findings that food handler hygiene had a major effect on the incidence of pathogenic Escherichia coli contamination. Contaminated food, thus, can pose dangers to humans.

The results of this study are commensurate with research conducted by Romanda et al. (2016), who discovered Escherichia coli in food samples on the food management sites around the buffer area of Adi Soemarmo Airport, Surakarta. The presence of Escherichia coli in food was correlated with poor personal hygiene in food handlers, for example, not using 
head coverings which may bring to crosscontamination during the food processing. The hands of food handlers are vectors of transmission for food borne disease (Lambrechts et al. 2014). If employees or food handlers are aware of and understand the importance of personal hygiene and health care, food safety will also improve. It is one of the basic requirements for food management in Indonesia since it can prevent food poisoning and food borne diseases.

Water sources contaminated by pathogenic bacteria can also pose risks to human health. Contaminated groundwater poses a high risk to public health because groundwater is a main source of drinking water. A study conducted by Rifta et al. (2016) stated that ice cubes using well water as raw material were proven to be positive for the Escherichia coli bacteria. Well water is more likely to be contaminated by bacteria than PDAM water.

The presence of pathogenic bacteria in food or beverages can be attributed to improper food storage. This study found that one of the food management sites processed food on an open shelf. Uncovered food storages can be contaminated by dust, insects, and microorganisms, which can reduce the quality of food and make the food unsafe for consumption. This is in line with Yunus's research which states that a food storage had a significant relationship with the occurrence of Escherichia coli contamination in food at restaurants in Padang, Manado, and Bitung cities. Processed food requires more attention in terms of food storage. Storage for processed food should not be attached to walls or floors and be protected and free from dust, insects, harmful chemicals, and other animals (Yunus et al. 2015).

The increase in the number of types of microbes in food can be due to improper use of tools, for example, the use of one knife for cutting both raw food and cooked or processed food. Equipment that is not well-washed before use can also increase the number of microbes in food (Suryani, 2014).

\section{Bacteriological Equipment Quality on Food Management Sites at Terminal 1 of Juanda Airport, Surabaya}

The results of this study indicated that all cutlery samples from the food management sites at Terminal 1 of Juanda Airport did not meet the health requirements as specified in the Regulation of the Indonesian Ministry of Health Number 1098 of 2003 concerning Restaurant Hygiene and Sanitation.

Table 3 shows the results of the bacteriological examination of cutlery samples using cotton swabs. All equipment samples were not found to have Escherichia coli, but all cutlery samples had an ALT value of more than 0 (zero) or exceeding the threshold value, meaning they did not meet the health requirements.

Based on the regulation, the number of germs on tableware should be 0 (zero) (Indonesian Ministry of Health, 2003). It was obtained from the ALT test which is the calculation of the number of microorganisms in general based on a large group such as bacteria, microalgae, or other bacterial groups but not specifically based on types of microorganism. ALT shows the number of bacteria that grow and develop in samples and can be a reference to determine the quality and safety of simplicia.

The presence of germs on utensils can be due to non-optimal washing of cutlery. As the four food management sites were surveyed, only one food management site used hot water to disinfect eating and cooking utensils. Hot water as disinfection can kill pathogenic bacteria that stick to tableware and cooking utensils. However, the laboratory results showed that the presence of column was still found in the cutlery although it was washed with hot water. This can happen because of higher demands in food causing food management inoptimal. To supply more cutlery, employees dry it with a cloth to make it available more quickly. Unclean dryer 
wipes can be a source of germ or bacterial contamination on cutlery. Apart from poor washing of cutlery, bacterial contamination on cutlery can also be caused by poor personal hygiene practices among employees, such as avoiding to handwashing and storing cutlery in open places.

The results of this study are similar to Budon's in that all the tableware used at the canteen had an exceeding number of germs. In washing utensils, some steps include removing food scraps, using soap or detergent, using a washing tub, not soaking, and not draining the utensils or not drying it with a rag. All canteens did not store cutlery in closed cupboards or shelves (Budon, 2013).

Research conducted by Suryani (2014) found that unstandardized sanitation facilities could increase potential growth of germs on tableware. Likewise, washing of cutlery has a relationship with the number of germs on eating utensils at restaurants in the Depok Beach tourism area. Meanwhile, another opinion mentions that the number of germs that exceeds the threshold value on glass cutlery is probably caused by washing methods without disinfectants or with stagnant water (Yulia, 2016). Factors that affect the number of germs in food equipment include the source and quality of water for washing, washing method, use of disinfectants, pollution from wind, room conditions, and storage racks for cutlery (Khaldun and Baharuddin, 2018).

Cutlery should be washed in three tubs, which are a washing tub, a rinsing tub, and a rinsing tub with disinfectant Used utensils should be washed thoroughly using hot water and soap. Equipment that has been washed and disinfected should be completely drained on a stainless steel rack until it dries on its own (Haderiah et al. 2015). It is not recommended to use a cloth or napkin for drying the tableware. If the cloth or napkin used is not clean (i.e., stained, damp, and unpleasant), it will cause bacterial contamination on the tableware. A damp cloth can be a breeding ground for bacteria. A stained and unpleasant cloth can contribute to the number of bacteria on the tableware (Fadhila et al. 2015).

\section{CONCLUSION}

Based on the results, all food management sites at Terminal 1 of Juanda Airport, Suabaya surveyed in February 2019 met the sanitation requirements and followed proper sanitation hygiene guidelines. However, they did not meet the required bacteriological quality of the equipment due to exceeding ALT value as specified in the Regulation of the Indonesian Ministry of Health Number 1098 of 2003 concerning Restaurant Hygiene and Sanitation. In terms of the bacteriological food quality, most of the food management sites at Terminal 1 of Juanda Airport met the health requirements as recommended.

Food management site owners need to repair some washing tubs that must have three wash basins and equipment according to the standrad. Besides, the Class 1 Surabaya Port Health Office needs to carry out routine education and training on food sanitation hygiene for improving food quality. This effort may increase the knowledge and awareness of food handlers and food management site owners.

\section{REFERENCES}

Amikawati, H., Yuliani, Y., and Broto, S. (2017). Kajian Uji Petik Kualitas Makanan di Tempat Pengelolaan Makanan (TPM) Kabupaten Sleman Tahun 2016. Jurnal Human Media, 11(1), 1-18.

BPOM RI. (2018). Laporan Tahunan Badan POM RI Tahun 2017. Jakarta: Badan POM RI.

Budon, A. S. (2013). Studi Kualitas Bakteriologis Air Pencucian dan Peralatan Makan di Kantin UIN Alauddin Makassar. Makassar: Universitas Islam Negeri Alauddin Makassar. 
Elfidasari, D., Saraswati, A. M., Nufadianti, G., Samiah, R., and Setiowati, V. (2011). Perbandingan Kualitas Es di Lingkungan Universitas Al Azhar Indonesia dengan Restoran Fast Food di Daerah Senayan dengan Indikator Jumlah Escherichia coli Terlarut. AlAzhar Indonesia Seri Sains Dan Teknologi, 1(1), 18-23.

Fadhila, M. F., Wahyuningsih, N. I., and D. Hanani, Y. (2015). Hubungan Higiene Sanitasi dengan Kualitas Bakteriologis pada Alat Makan Pedagang di Wilayah Sekitar Kampus UNDIP Tembalang. Jurnal Kesehatan Masyarakat, 3(3), 769-776.

Fadly, M., Anwar, and Natsir, M. F. (2017). Kualitas Sanitasi Rumah Makan dan Restoran di Objek Wisata Pantai Losari Kota Makassar. Jurnal Fkm Unhas, 5.

Haderiah, Sulasmi, and Novi. (2015). Studi Kualitas Bakteriologis Peralatan Makan pada Rumah Makan di Kota Makassar. HIGIENE: Jurnal Kesehatan Lingkungan, 1(2), 124128.

Herman, Napirah, M. R., \& Sherlina. (2015). Faktor-Faktor Perilaku Hidup Bersih dan Sehat yang Berhubungan dengan Kejadian Foodborne Disease pada Anak di Sekolah Dasar Negeri (SDN) Inpres 3 Tondo Kota Palu. Jurnal Kesehatan Tadulako, 1(2), 114.

Indonesian Ministry of Health. (2007). Keputusan Menteri Kesehatan Republik Indonesia Nomor 431 Tahun 2007 tentang Pedoman Teknis Pengendalian Risiko Kesehatan Lingkungan di Pelabuhan/Bandara/Pos Lintas Batas. Jakarta: Indonesian Ministry of Health.

Indonesian Ministry of Health. (2014). Perilaku Mencuci Tangan Pakai Sabun di Indonesia. Pusat Data Dan Informasi. Jakarta Selatan: Indonesian Ministry of Health.

Indonesian Ministry of Health. (2018).
Profil Kesehatan Indonesia 2017.

Pusat Data Dan Informasi. https://doi.org/10.1007/s13398-0140173-7.2

Indonesian Ministry of Health. (2003). Keputusan Menteri Kesehatan Republik Indonesia Nomor 1098 Tahun 2003 tentang Persyaratan Higiene Sanitasi Rumah Makan dan Restoran. Jakarta: Indonesian Ministry of Health.

Jiastuti, T. (2018). Higiene Sanitasi Pengelolaan Makanan dan Keberadaan Bakteri pada Makanan Jadi di RSUD Dr. Harjono Ponorogo. Jurnal Kesehatan Lingkungan, 10(1), 13-24.

Khaldun, S., and Baharuddin, A. (2018). Studi Komparatif Jumlah Kuman Pada Perlatan Makan Pada Pencucian Dengan Perendaman Dan Air Mengalir. Sinergitas Multidisiplin Ilmu Pengetahuan Dan Teknologi, 1, 332-339.

Kumalasari, R. C. (2003). Hubungan Sanitasi dengan Status Bakteriologis (Status Koliform dan Keberadaan Salmonella sp) pada Jajanan di Sekolah Dasar Wilayah Kecamatan Tembalang, Semarang. Jurnal Kesehatan Masyarakat, 4(3), 98-107.

Kurniadi, Y., Saam, Z., \& Afandi, D. (2013). Faktor Kontaminasi Bakteri E.coli pada Makanan Jajanan di Lingkungan Kantin Sekolah Dasar Wilayah Kecamatan Bangkinang. Jurnal Ilmu Lingkungan, 7(1), 28-37.

Lambrechts, A., Human, I., Doughari, J., \& Lues, J. (2014). Bacterial Contamination of the Hands of Food Handlers as Indicator of Hand Washing Efficacy in Some Convenient Food Industries. Pakistan Journal of Medical Sciences, 30(4), 755-758. https://doi.org/10.12669/pjms.304.440 0

Mutiarani, P. T. (2017). Studi Sanitasi Kapal Kargo dan Keberadaan Bakteri E.Coli pada Makanan Jadi di Wilayah Pelabuhan Tanjung Perak Surabaya. Jurnal Kesehatan Lingkungan, 9(2), 
111-121.

https://doi.org/10.20473/jkl.v9i2.2017 .11-121

Ministry of Health. (2000). Prinsip-Prinsip Higiene dan Sanitasi Makanan. Jakarta: Depkes RI.

Nuraini, and Hajimi. (2014). Faktor-faktor yang Berhubungan dengan Keberadaan Tikus di Kantin Pelabuhan Dwikora Kota Pontianak. Jurnal Kesehatan Masyarakat Khatulistiwa, 1(1), 47-56. https://doi.org/10.29406/jkmk.v1i1.98 0

Pulungan, S. R., Marsaulina, I., \& Naria, E. (2013). Higiene dan Sanitasi Terminal Pelabuhan Roro Kota Dumai Tahun 2012. Lingkungan Dan Kesehatan Kerja, 2(3), 1-6.

Rananda, R. M., Djamal, A., \& Julizar. (2016). Identifikasi Bakteri Escherichia coli O157: H7 dalam Daging Sapi yang Berasal dari Rumah Potong Hewan Lubuk Buaya. Jurnal Kesehatan Andalas, 5(3), 614-618.

Saridewi, I., Pambudi, A., \& Ningrum, Y. F. (2016). Analisis Bkteri Escherichia coli pada Makanan Saji di Kantin Rumah Sakit X dan Kantin Rumah Sakit Y. Bioma, 12(2), 21-34. https://doi.org/10.21009/bioma12(2).4

Sudjanto, H., Ismail, M., \& Fitri, H. R. (2016). Rancangan Alat Penghancur Sampah pada Grease Trap untuk Sistem Sanitasi di Bandar Udara
Internasional Kualanamu Medan. Jurnal Ilmiah Aviasi Langit Biru, 9(3), 33-42.

Suryani, D. (2014). Keberadaan Angka Kuman Ikan Bawal Bakar dan Peralatan Makan Bakar. Jurnal Kesehatan Masyarakat, 9(2), 191196. https://doi.org/ISSN 1858-1196

Yogisutanti, G., Hotmaida, L., Fuadah, F., Ardayani, T., Taneo, A. G., \& Rinaldy, F. (2018). Upaya Peningkatan Pengetahuan tentang Pentingnya Saluran Pembuangan Air Limbah Rumah Tangga di Kelurahan Ciseureuh Kecamatan Regol Kota Bandung. Jurnal Pengabdian Kepada Masyarakat UBJ, 1(2), 116-124. https://doi.org/10.31599/jabdimas.v1i 2.345

Yulia. (2016). Higiene Sanitasi Makanan, Minuman dan Sarana Sanitasi terhadap Angka Kuman Peralatan Makan dan Minum pada Kantin. Jurnal Vokasi Kesehatan, 2(1), 55-61.

Yunus, S. P., Umboh, J. M. L., \& Pinontoan, O. (2015). Hubungan Personal Higiene dan Fasilitas Sanitasi dengan Kontaminasi Escherichia coli pada Makanan di Rumah Makan Padang Kota Manado dan Kota Bitung. Jurnal Ilmu Kesehatan Masyarakat, 5(2), 210-220. https://doi.org/10.1016/j.biotechadv.2 010.08.010 